\title{
Translanguaging in the Polish educational context: Lessons learnt from IB schools
}

\author{
Piotr Romanowski \\ University of Warsaw
}

(Text received March 10 2019; accepted March 13 2019; final version March 20 2019)

DOI: https://doi.org/10.5565/rev/jt13.795

\begin{abstract}
Poland's foreign language teaching and language policy have been affected by tremendous changes in the last decades. Not only bilingual sections in secondary schools have mushroomed, but also international schools with instruction in a foreign language, mainly English, within the International Baccalaureate Diploma Programme (IBDP) started their existence in 1993. This paper draws on the translanguaging pedagogy as used in the selected secondary schools with IBDP. The schools provide evidence for the stance that most students, if not all, are multilingual in such teaching environments. Therefore, they apply multiple strategies to benefit from their linguistic repertoires. In addition, the teachers perceive such practices as positively affecting the students' performance and allowing them to more rapidly acquire the imparted content as well as further develop their linguistic proficiency. The overriding aim of this study is to identify the situations when the students translanguage and analyze their linguistic behaviour as well as explore the functions of students' translanguaging practices.
\end{abstract}

Keywords: translanguaging, multilingual education, IBDP, English, bilingualism

Resumen: En las últimas décadas, la enseñanza de idiomas extranjeros y la política lingüística de Polonia se han visto afectadas por importantes cambios. No solo han crecido rápidamente los departamemtos bilingües en las escuelas secundarias, sino que también las escuelas internacionales con instrucción en un idioma extranjero, principalmente inglés, dentro del Programa de Diploma del Bachillerato Internacional (IBDP) comenzaron su existencia en 1993. Este artículo explora la llamada pedagogía translingüística que se lleva a cabo en una selección de escuelas secundarias con el programa IBDP. Las escuelas proporcionan evidencia de que la mayoría de los estudiantes, si no todos, son multilingües en dichos entornos de enseñanza. Por lo tanto, aplican múltiples estrategias para beneficiarse de sus repertorios lingüísticos. Además, los maestros perciben que tales prácticas afectan de manera positiva el rendimiento de los estudiantes y que les permiten adquirir más rápidamente el contenido impartido, así como desarrollar su competencia lingüística. El objetivo primordial de este estudio es identificar las situaciones en las que los estudiantes hablan el idioma y analizar su comportamiento lingüístico, así como explorar las funciones de las llamadas prácticas translingüísticas.

Palabras clave: translenguar (translanguaging), educación multilingüe, IBDP, inglés, bilingüismo

Resum: En les darreres dècades, l'ensenyament d'idiomes estrangers i la política lingüística de Polònia s'han vist afectats per importants canvis. No només han crescut 
ràpidament els departaments bilingües a les escoles secundàries, sinó que també les escoles internacionals amb instrucció en un idioma estranger, principalment anglès, dins el Programa de Diploma del Batxillerat Internacional (IBDP) van començar la seva existència el 1993. Aquest article explora l'anomenada pedagogia translingüística que es porta a terme en una selecció d'escoles secundàries accollides el programa IBDP. Les escoles proporcionen evidència que la majoria dels estudiants, si no tots, són multilingües en aquests entorns d'ensenyament. Per tant, apliquen múltiples estratègies per beneficiar-se dels seus repertoris lingüístics. A més, els mestres perceben que aquestes pràctiques afecten de manera positiva el rendiment dels estudiants $\mathrm{i}$ que els permeten adquirir més ràpidament el contingut impartit, així com desenvolupar la seva competència lingüística. L'objectiu primordial d'aquest estudi és identificar les situacions en què els estudiants parlen l'idioma i analitzar el seu comportament lingüístic, així com explorar les funcions de les anomenades pràctiques translingüístiques.

Paraules clau: transllenguar (translanguaging), educació multilingüe, IBDP, anglès, bilingüisme

\section{Introduction}

In recent years Poland has undergone significant changes affecting various spheres of life, especially education. With the fall of communism in 1989 and resulting political transformations and access to the EU in 2004, Polish teachers and students were able to move freely across the continent, study at European universities, attend international conferences and thus learn foreign languages at a much faster pace. The role of English has evolved at an unprecedented speed and level. It is no longer an elitist language, but a widely used medium of communication taught in all educational settings (Romanowski, 2016). However, many linguists perceive the growing role of English as posing a threat to multilingualism in Europe (Phillipson, 2015). Contrary to what they claim, if teachers and students are using not only English but also one or more additional languages, this would indicate that using English as Medium of Instruction (EMI) may not cause any risk to multilingualism in Europe. In addition, little is known about the auxiliary or supportive role of English in the Polish educational context. The fact that English is considered to be the prevalent medium of instruction in international schools is the result of both students' and teachers' orientations and attitudes expressed in their emerging ecological hierarchy. While international schools are no longer unique places where English is the medium of instruction, they have been offering their students the exclusive possibility of instruction within the International Baccalaureate Diploma Programme (IBDP) since 1993. At the moment there are over thirty institutions of 
this kind in Poland located in major cities, however more and more schools start their existence on a yearly basis.

In this article I attempt to describe translanguaging practices in international schools with the aim of focusing on the situations when and where students most often translanguage. I understand the concept of translanguaging as a languaging practice that integrates other linguistic resources based on a pedagogical principle that deliberately draws on students' plurilingual competencies. Hence, the exploitation of the students' multilingual repertoires as resources for learning is strongly recommended (Beacco, 2005). What will be analysed is the systematic use of students' talk in classroom interactions to envisage the functions translanguaging practices perform. The study will take into account both on-task and informal talk. It is assumed that such linguistic behaviour positively affects the acquisition of taught content and further language proficiency development of the whole repertoire. It is posited that through translanguaging pedagogy new knowledge in mainstream education can be acquired (Creese \& Blackledge, 2010). To better understand the full potential of translanguaging practices and describe the students' learning and construction of knowledge in the observed classes, the sociocultural perspective, with a stance that learning from social and cultural interactions should prevail, has been adopted for the needs of the present analysis (Díaz-Rico \& Weed, 2010; Swain \& Deters, 2007).

At this point, it is also vital to note that Poland and the vast majority of Polish schools are monolingual although minority and regional languages exist and some of them have been successfully adopted in our system of education. The present study is based on the observations conducted in three international secondary schools (students aged 16-19) where multilingual practices have always been in operation due to the fact that IB Schools in Poland target Polish and foreign students of over sixty nationalities. The majority of the students have resided in Poland for a number of years, hence they have a good command of Polish.

\section{English language education in Poland now and then}

The political transformation after 1989 led to changes in education in Poland. The present-day system of education is based on the Act of Implementation of the Education System Reform of 8 January 1999. Its aim was to implement modifications to improve the overall level of Polish education by increasing educational opportunities for students and a general quality of education in the country. A primary school cycle of 6 years was introduced, to be followed by 3 years of lower-secondary school and 3- or 4-years of secondary school (general upper- 
secondary or technical) to achieve better results. Hence, it became obligatory for all the children until the age of 18 to attend a school of their choice. In this new structure English took on the role of the most popular foreign language taught across the country, just as in other European states. After 2004, when Poland joined the European Union, the Polish education system favoured English as the main foreign language even more. In the past, mainly due to historical influences, Russian and German were the most desired foreign languages in education (Górowska-Fells, 2012).

Children in Poland start their foreign language education as early as pre-school. Every child has a chance to attend so-called preparatory English language classes. It must be emphasised that teaching English in a pre-school is a fairly new concept, because previously pupils would start learning a foreign language when they were in grade 4 of primary school. It is believed that children starting their language education between the age of 3 and 6 will achieve better results and acquire it faster and with more lasting results. Education in grades 1-3 of primary school is based on integrated teaching where English is combined with Maths, Natural Sciences, Musical or Physical Education. The average exposure to English oscialites between 180-240 hours in total. As far as the teaching of English in grades 4-6 is concerned, the overall exposure increases to 360 hours and a modern foreign language (either English or German) is taught separately four times a week. In lower-secondary schools, pupils aged 13 to 16 are required to study not one foreign language, but two. Normally, it is English and German, rarely French, Spanish or Italian. There are 540 hours devoted to both languages, and obviously English is the leading foreign language. The last stage of education involves upper-secondary schools where exposure to English is 450 hours over 3 years, whereas another foreign language (German, French, Spanish or Italian) is taught 2 hours a week throughout the whole cycle (180 hours in total).

It needs to be stated clearly that pupils in Poland start their language education early. Engaging students in exchange programmes, i.e. Erasmus + where they have a chance to go abroad and use the language they learn, has become much of a necessity for many schools and educators. Also, the fact that more and more students, not only those living in urban areas, but also in rural ones, have access to the Internet makes studying English more accessible. Last but not least, learners' eagerness to be familar with the latest films, video games or songs determines much higher exposure to a foreign language outside the classroom. This all affects their acquisition and boosts their proficiency. 


\section{The International Baccalaureate Diploma Programme (IBDP)}

The IB Diploma Programme (DP) is a challenging two-year university-preparation programme for students aged 16 to 19 , which has been developed in collaboration with educators and researchers from around the world. It offers research-based education aimed at enhancing disciplinary and interdisciplinary knowledge. It teaches critical thinking, academic writing, selection of information, and many more skills. The DP promotes language and literacy, multilingualism, the social sciences, experimental sciences, mathematics, the arts, interdisciplinary learning, etc. Teaching of the IBDP is possible in English, Spanish and French with elements in German, Chinese, Arabic, Turkish and Japanese. The DP includes six subject groups:

1. Studies in language and literature - they constitute the student's native language (over 55 different languages are available);

2. Language acquisition - it represents an additional modern language available at the standard (SL) or higher level (HL);

3. Individuals and societies - one subject is chosen from the area of humanities or social sciences: Business Management, Economics, Geography, Global Politics, History, Information Technology in a Global Society, Philosophy, Psychology, Social and Cultural Anthropology and World Religions;

4. Sciences - experimental science courses: Biology, Chemistry, Physics, Computer Science, Design Technology and Sports, Exercise and Health Science;

5. Mathematics - a wide range of mathematical courses is offered: Mathematical Studies (SL), Mathematics (SL), Mathematics (HL), Further Mathematics (either SL or HL).

6. The Arts - students can choose Dance, Music, Theatre, Visual Arts, or Film (cf. IBO 2012b).

Students select one subject from each group and at least two foreign languages. Three subjects are obligatory at the higher level (HL) and they are studied for 240 hours, whilst standard level (SL) courses are taught for 150 hours.

The IBDP was first introduced in 1968 and was immediately well received. In 2016, there were 5,578 programmes offered worldwide, across 4,335 schools. Between 2011 and 2016, the number of IB programmes offered worldwide grew by $46.4 \%$. In Poland the first IB Diploma Programme was introduced in 1993 and now the number of schools where it is offered amounts to 39, although altogether there are 44 IB World schools. The remaining five schools provide instruction at the two other IB levels: the Primary Years Programme and 
Middle Years Programme. Currently, 23 Polish universities recognise the IB with official policies for admitting IB students to their courses.

\section{Theoretical underpinnings of translanguaging}

The history of translanguaging is firmly grounded in the field of bilingual education. The term itself was first coined in Welsh as trawsieithu by bilingual education researcher Cen Williams (1996), who observed Welsh-English bilingual secondary school learners' language practices. Baker (2006, p. 297) also affirms that the notion refers to a communicative function of receiving input in one language and providing output in another. Although the term itself was initially created to define and depict bilingual language use in Wales, it has been extended to decribe the omnipresent creativity of language users in other teaching/learning settings. García (2009, p. 45) defines the term as "multiple discursive practices in which bilinguals engage to make sense of their bilingual worlds". In other words, speakers engaged in translanguaging select language features and employ them in their communicative practices to meet their communicative needs (García, 2011). Li Wei (2011) looked further at the creativity of multilingual speakers using languages to gain knowledge, to articulate their thoughts and to communicate. For him translanguaging involves moving between various linguistic structures, sometimes going beyond them. Similarly, Canagarajah (2011) asserts that translanguaging does not occur out of context. It is connected to the myriad discursive practices found in bilingual and/or multilingual classrooms. This phenomenon, if used strategically, can lead to successful content acquisition. García and Li Wei (2014) further elaborate that, due to the fact that human interactions have become so complex, translanguaging requires its separate space where languages can interplay dynamically. Translanguaging spaces, allowing for the transmission of information, offer an abundance of alternatives whereby teachers and students voice their emerging hypotheses created to make sense of the languages surrounding them. The complexity and hybridity of translanguaging result from a huge diversity of linguistic resources and cultural backgrounds represented by speakers. For the proponents of translanguaging, languages are not treated as distinct systems or codes, but they form interconnected repertoires. Thus, at the same time, such linguistic terms as code-switching or code-mixing are called into question. Unlike code-switching, translanguaging does not refer to the use of two separate languages or the shift of one language or code to the other (Hornberger \& Link, 2012). It allows for the intermingling of 
linguistic features that have been somehow administratively and artificially assigned to a particular language or variety.

García and Leiva (2013) argue that translanguaging means acting in a new languaging reality, which is open, independent and fluid. Through the use of translanguaging speakers construct and negotiate meanings. What we talk about is languaging perceived as an ongoing process shaped as speakers interact with one another in specific social contexts. Such practices lead to constant and active invention of new realities through social action.

As stated earlier, important avenues of research have begun to question the validity of boundaries around languages. For Li Wei (2011), similarly as for García (2011), translanguaging embraces a wide array of linguistic performances of multilingual speakers aimed at transcending the interlocked structures, the transmission of information and, what is significant, the representation of values, identities and relationships. Therefore, translanguaging creates a social space for each multilingual speaker by bringing together their experience, attitudes, beliefs and ideology as well as cognitive capacity into one meaningful performance, and transforming it into a lived experience. Through the creation of translanguaging space, multilingual language users are able to generate new ideas, values and practices affecting their interactions.

A growing body of research on the emergent paradigm of translanguaging has been conducted in order to envisage its possible consequences for multilingual classrooms (Creese \& Blackledge, 2010; Mazak \& Herbas-Donoso, 2014). In multilingual communities speakers of different language practices select certain features from their multilingual repertoires to converse in various situations and on the topics of their preference. In line with this implication, Lewis, Jones and Baker (2012) state that in classrooms translanguaging frequently means planned practices with a pedagogical emphasis. Thus, very often in educational contexts translanguaging is advocated with a view to helping students develop their literacy skills and academic language proficiency. Last but not least, Creese and Blackledge (2010) argue that translanguaging as a pedagogical approach serves to enhance teaching and indexes the speakers' shifting of multilingual and multicultural identities.

\section{Applied methodology}

To easily identify the translanguaging behaviour of the students involved in the present study, observations of classes were conducted in the three schools chosen randomly where in each case the head teachers had given their consent for the classes to be observed. These were 
unstructured (naturalistic) observations focusing on studying spontaneous behaviour of participants in natural surroundings, i.e. classrooms. This type of observation was employed in the hope that it would suggest further avenues of inquiry and generate new ideas, not thought of before. In addition, the observation is also in line with ethnographic methodology. It employs constant comparative characteristics of data collection (Heath \& Street, 2008), whereby researchers recursively reflect on the data from observations and conceptual insights from the literature to inform ongoing and emerging lines of inquiry, constituting a 'back-andforth' observing, noting, reading, thinking approach. Gumperz and Hymes (1972) assert that samples of language must be captured in naturally occurring social settings. Therefore, in the present investigation data collection imposed extensive observation of students' interactions with one another and with their teachers.

\section{Study context: schools, students and teachers}

The three schools involved in the investigation are situated in the Polish capital city of Warsaw. Out of twelve schools functioning in Warsaw, only three agreed to participate in the study. They will be referred to as School 1, School 2 and School 3 to provide anonymity. All of them are authorised centres for IBDP and have existed on the educational market from 4 to 10 years. Instruction in the selected schools is offered in English.

The study was conducted among 18 and 19-year-old learners from diverse linguistic backgrounds. As stated earlier, for all the participants English was the language of instruction. It was also the mother tongue for some students whose background was in English-speaking countries. Other home languages used in the study groups involved: French, Spanish, Chinese, Hungarian, Czech, Polish and Ukrainian (altogether 8). All the foreign students had a considerable knowledge of Polish as they had resided in Poland for at least 5 years. They came from middle-class families. Their parents were either employed by transnational companies or basically had their roots in Poland, and that is why they live in Poland.

The classes where translanguaging practices were observed and further analysed were in Geography, within the area of humanities or social sciences. The sample of students in the present investigation was 70 . Out of all the surveyed students $60 \%$ were female $(n=42)$ and $40 \%$ were male $(n=28)$. Student participants represented 9 countries: Poland, the USA, the UK, Ukraine, France, Spain, the Czech Republic, Hungary and China. Out of 70 participants 37 (53\%) students were Polish and they constituted the largest group considering all the nationalities included. Other groups significant in size were as follows: 10 English-speaking 
students (6 students from the USA and 4 students from the UK) and 10 Ukrainian students. Each group respectively formed $14 \%$ of the whole sample. The remaining nationalities represented included: Chinese (4 students), Hungarian (3 students), French (2 students), Spanish ( 2 students) and Czech ( 2 students). The respective languages used by the observed students and further analysed in terms of translanguaging are presented below.

Table 1. Students and their languages used in translanguaging

\begin{tabular}{|c|c|c|c|c|}
\hline Nationality & School 1 & School 2 & School 3 & Total \\
\hline Polish & 12 & 10 & 15 & 37 \\
\hline English & 3 & 5 & 2 & 10 \\
\hline French & 2 & 0 & 0 & 2 \\
\hline Spanish & 0 & 0 & 2 & 4 \\
\hline Chinese & 0 & 2 & 0 & 3 \\
\hline Hungarian & 0 & 3 & 0 & 2 \\
\hline Czech & 2 & 0 & 3 & 70 \\
\hline Ukrainian & 4 & 23 & 24 & 10 \\
\hline Total & 23 & 3 & & 2 \\
\hline
\end{tabular}

It is essential to clarify that all the participants in the sample were multilingual. Among the 70 students, $80 \%(n=56)$ could speak two foreign languages and the remaining $20 \%$ of the surveyed students $(n=14)$ were able to speak three foreign languages. For 33 students (47\%) Polish was one of the foreign languages. 21 students $(30 \%)$ declared their proficiency in this language; however the remaining $17 \%(n=12)$ classified their command of Polish as B2 according to CEFR, hence they could not be regarded as fully proficient users. With regard to English, which was the medium of instruction, out of 60 students for whom this language was not the home language, 42 participants $(70 \%)$ reported a fairly high proficiency and only 18 described their command as B2 according to CEFR (30\%). Additionally, all the Ukrainian students $(n=10)$ declared a high proficiency in Russian, the language still spoken widely in the territory of Ukraine. They also selected Russian as an additional modern language studied at the higher level (HL) for IBDP. Furthermore, the two 
Spanish students declared their fluency in French and the French students respectively reported that they were fluent in Spanish. They selected these languages as additional modern languages to be studied at the higher level (HL) within the IBDP. Other foreign tongues studied by the remaining surveyed students included: German at the standard level for the Polish students $(n=37)$; and French at the standard level for the students from the UK and the USA $(n=10)$. The Chinese, Hungarian and Czech students $(n=9)$ reported that they selected Polish as a modern language at the higher level.

There were 3 Geography teachers ( 2 female and 1 male) involved in the study and all of them were Polish. Their age spanned from 35 to 45 years old. Their declared and observed level of proficiency in English was between $\mathrm{C} 1$ and $\mathrm{C} 2$. Therefore, it is assumed that the linguistic competence was high enough for them to carry out all the instruction in English.

The three groups of students (one group from each school) were observed for a period of eight weeks each. Classroom observation was suitable for collecting the information on the students' and teachers' language choices and practices in natural settings to evidence the frequent application of translanguaging. Each observed class lasted for 45 minutes, thus 24 classes were observed altogether ( 8 classes in each school, 1 observation per week). The ethnographic field notes of 24 observations between October and December 2017 formed the basic material for data analysis.

\section{Data collection and analysis}

In the observations, the author concentrated on the languages used in the speech events analysed in order to identify the possible patterns of translanguaging. In particular, the focus was on the frequency of occurrence of particular language combinations, and thus the frequencies of interactions were counted. What was also essential for the researcher was the purpose of each stretch of oral discourse. All the interactions were either classified as taskreferring or non-task-referring. In addition, it was imperative to know who was most frequently involved in translanguaging, whether it was student-teacher $(\mathrm{S}>\mathrm{T})$ translanguaging or student-student $(\mathrm{S}>\mathrm{S})$ translanguaging. All the results were calculated statistically and are showcased in the article.

\section{Language combinations in translanguaging}

Although no distinction between individual languages is made in translanguaging and speakers' repertoires are regarded to be fluid and existing in an ecological system of 
interdependence, it seems circumstantiated for the purpose of the study to depict the multilingual patterns of the students observed in the IBDP classes. The ethnic diversity of the observed classes was discussed previously, hence in relation to the possible variety as many as 14 translanguaging patterns were noted where each of them belonged to a different group of students.

Based on the results of the observation, it occurred that both English and Polish were the most frequently used languages for translanguaging. It is obvious that English must dominate as it is the language of instruction and shared by all. On the other hand, it was not surprising that Polish was also often spoken due to the fact that the study was conducted in Polish schools and all the students had a fairly good command of the language. In addition, some translanguaging was observed between French and Spanish as these two languages come from the same family and their speakers find it fairly easy to learn other Romance languages. The French and Spanish students turned out to be quite fluent in the respective foreign languages. The results regarding the frequency of occurrence of translanguaging between the language combinations stated above are as follows:

Table 2. Translanguaging in interactions and their frequency of occurrence

\begin{tabular}{|c|c|c|}
\hline $\begin{array}{c}\text { Language combinations for } \\
\text { translanguaging }\end{array}$ & $\begin{array}{c}\text { Speech acts / interactions } \\
\text { (task and non-task referring) }\end{array}$ & $\begin{array}{c}\text { Frequency of occurrence } \\
\%\end{array}$ \\
\hline $\mathrm{PL} \leftrightarrows \mathrm{EN}$ & 312 & 32.9 \\
\hline $\mathrm{PL} \leftrightarrows \mathrm{ES}$ & 44 & 4.6 \\
\hline $\mathrm{PL} \leftrightarrows \mathrm{F}$ & 38 & 1.5 \\
\hline $\mathrm{PL} \leftrightarrows \mathrm{CN}$ & 14 & 2.8 \\
\hline $\mathrm{PL} \leftrightarrows \mathrm{H}$ & 27 & 0.9 \\
\hline $\mathrm{PL} \leftrightarrows \mathrm{CZ}$ & 9 & 7.8 \\
\hline $\mathrm{PL} \leftrightarrows \mathrm{UA}$ & 73 & 10 \\
\hline $\mathrm{EN} \leftrightarrows \mathrm{ES}$ & 95 & 6.4 \\
\hline $\mathrm{EN} \leftrightarrows \mathrm{F}$ & 61 & \\
\hline
\end{tabular}




\begin{tabular}{|c|c|c|}
\hline $\mathrm{EN} \leftrightarrows \mathrm{CN}$ & 28 & 3 \\
\hline $\mathrm{EN} \leftrightarrows \mathrm{H}$ & 52 & 5.5 \\
\hline $\mathrm{EN} \leftrightarrows \mathrm{CZ}$ & 66 & 7 \\
\hline $\mathrm{EN} \leftrightarrows \mathrm{UA}$ & 118 & 12.4 \\
\hline $\mathrm{ES} \leftrightarrows \mathrm{F}$ & 11 & 1.2 \\
\hline & 948 & \\
\hline
\end{tabular}

The results confirm the dominance of Polish and English in relation to the extent the students sharing linguistic repertoires use translanguaging in their interaction (312 out of 948 interactions which accounts for 32.9\%). This combination is followed by English and Ukrainian (12.4\%) which might be due to the fact that as many as 10 students $(14 \%$ of the sample studied) constitute the biggest group of foreigners involved in the investigation, hence the frequency of Ukrainian in the translanguaging patterns is relatively high. The Polish/Ukrainian constellation is found to be the third most frequently occurring and is represented by 73 interactions constituting $7.8 \%$ of all the translanguaging in the present investigation. The other language combinations utilised in translanguaging comprise smaller numbers, thus the students sharing similar repertoires are thought to be often performing most of their speech either in English and/or Polish (See Table 2).

\section{Types of interaction}

The second research question of the present study addressed the types of speech acts where translanguaging occurred most frequently. To achieve this, possible interactions were divided into task-referring and non-task-referring (See Table 3). Within the task-referring speech acts, the following sub-types were further classified: explaining (i.e. giving instructions), elaborating (i.e. on topics or phenomena), translating (i.e. new words and phrases) or interpreting (i.e. cultural meaning). The non-task-referring sub-types included: chit-chat (i.e. after the task has been completed), requesting (i.e. school accessories), what might be called 'verbal fidgeting', playing with objects and muttering. Perhaps, the lists are not exhaustive, however these were the most typical behaviours related to interactions in translanguaging practices identified and categorised in the study. 
For the present analysis only the examples of translanguaging between Polish and English (312 altogether) were taken into consideration due to the complexity of all identified interaction patterns as well as the researcher's inability to identify those speech acts that involved French, Chinese, Hungarian, etc.

The table clearly indicates the predominance of translanguaging for the purpose of task-referring - 196 out of 312 situations (63\%). The speech acts relating to non-task activities constituted 116 interactions (37\%). This discrepancy signifies that translanguaging definitely serves pedagogic purposes as it is mostly observable in task-referring interactions. Perhaps, it is worth emphasising that the most representative examples reflect such student activities as translating (22\%) and explaining (19\%), which might indicate a necessity for further suggestions and/or explorations of the topics discussed. In addition, their prevalence implies a dialogic, critical and constructive character of translanguaging.

Table 3. Types of speech acts/interactions in translanguaging

\begin{tabular}{|c|c|c|}
\hline Types of interactions & $\begin{array}{c}\text { Speech acts / } \\
\text { interactions / situations } \\
\text { (312) }\end{array}$ & $\begin{array}{l}\text { Frequency of } \\
\text { occurence (\%) }\end{array}$ \\
\hline \multicolumn{3}{|c|}{ Task-referring interactions } \\
\hline explaining & 59 & 19 \\
\hline elaborating & 47 & 15 \\
\hline translating & 68 & 22 \\
\hline \multirow[t]{2}{*}{ interpreting } & 22 & 7 \\
\hline & 196 & $63 \%$ \\
\hline \multicolumn{3}{|c|}{ Non-task-referring interactions } \\
\hline chit-chat & 36 & 11.5 \\
\hline requesting & 8 & 2.5 \\
\hline fidgeting & 55 & 17.5 \\
\hline
\end{tabular}




\begin{tabular}{|c|c|c|}
\hline $\begin{array}{c}\text { playing with objects (tapping) } \\
\& \text { muttering (humming) }\end{array}$ & 17 & 5.5 \\
\hline & 116 & $37 \%$ \\
\hline
\end{tabular}

As can be seen from the table, verbal fidgeting (17.5\%) and chit-chat (11.5\%) were the most frequent non-task-referring occasions for students to translanguage. During the observations conducted it occurred that in many instances students applied translanguaging practices in situations when either their task was completed too soon or they were missing some information. In the first case, it is assumed that the observed students belonged to typical mixed-ability groups whereas in the second case the tasks were not clear enough and the students required further re-interpretation.

\section{Interactors in translanguaging}

One of the most challenging parts of the present study involved the identification of the translanguaging frequency among the major interactors. The collected classroom data was divided into the student-teacher $(\mathrm{S}>\mathrm{T})$ translanguaging and the student-student $(\mathrm{S}>\mathrm{S})$ translanguaging. To better understand the functions of translanguaging as a classroom pedagogy, observed instances of translanguaging were classified according to three strategies: explanatory strategies, managerial strategies and interpersonal strategies. However, this classification should not be generalised as it concerned only the context where the relevant study was conducted.

The explanatory strategies involved all the teachers' strategies aimed, for example, at explaining some new notions and elaborating on their definitions. Also, quite a few students employed explanatory strategies to translate the new concepts from English to Polish for their classmates. In general, the goal of these strategies was to provide cognitive scaffolding in situations where meanings are established.

The managerial strategies refer to the teachers' actions and involve classroom operations, such as: providing feedback, giving instructions, checking understanding of the taught content, assigning homework, etc.

Last but not least, the interpersonal strategies were mostly associated with the student-student translanguaging practices. In numerous instances, the students interacted with one another using the whole of their repertoires. The most recurrent actions or purposes were as follows: 
interpreting, translating and requesting. Most of the practices took place among the students sitting nearby.

From the findings of the present study, it can be affirmed that translanguaging practices occurred quite naturally and spontaneously. It is impossible to link them to any type of planned activity. They also revealed a huge potential for the existence of diversified levels of each language involved in the students' linguistic repertoires. This observation is in line with Canagarajah's (2011) research on translanguaging, who referred to it as a naturally occurring phenomenon among multilingual students using it strategically in the classroom to learn and be taught.

Table 4. Types of strategies in translanguaging practices

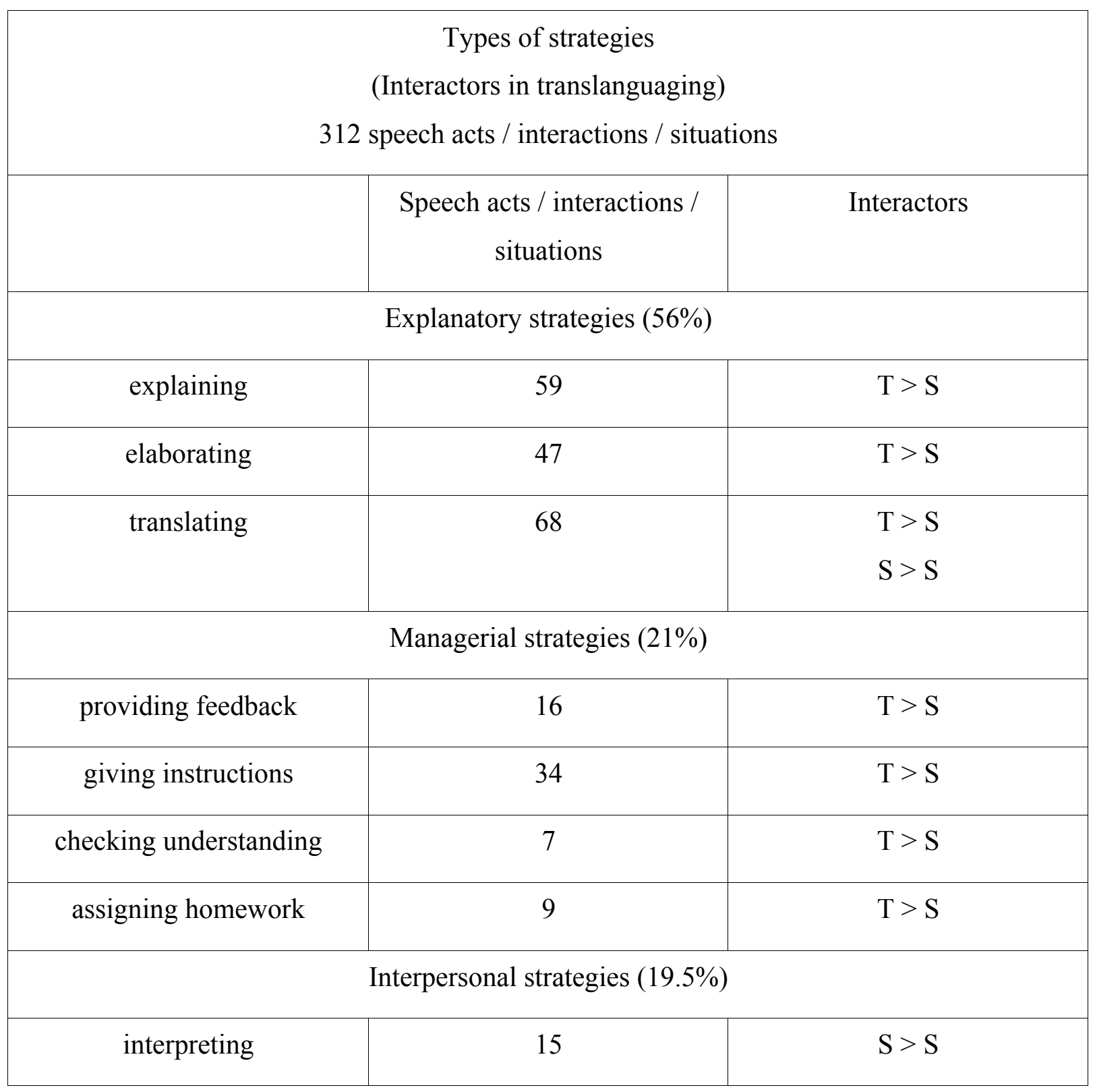




\begin{tabular}{|c|c|c|}
\hline translating & 38 & $\mathrm{~S}>\mathrm{S}$ \\
\hline requesting & 8 & $\mathrm{~S}>\mathrm{S}$ \\
& & $\mathrm{S}>\mathrm{T}$ \\
\hline \multicolumn{2}{|c|}{ Other types of strategies $(3.5 \%)$} \\
\hline non-classified actions & 11 & $\mathrm{~S}>\mathrm{T}$ \\
& & $\mathrm{T}>\mathrm{S}$ \\
& & $\mathrm{S}>\mathrm{S}$ \\
\hline
\end{tabular}

As can be seen in Table 4, the explanatory strategies in translanguaging practices accounted for the highest number of speech acts in the study (56\%). In terms of the main actors in such practices, it must be noted that they were closely related to the teachers' actions and all the translanguaging patterns embraced teacher-student $(\mathrm{T}>\mathrm{S})$ interactions. Also, the teachers initiated all the exchanges with students as all of them were labeled as: explaining, elaborating and translating. This happened due to the fact that the teachers saw miscomprehension and intended to increase the students' knowledge in both languages. These actions usually involve teachers' duties. In the case of translating, however, also students were actively involved as some of them helped other classmates to understand various concepts under discussion. Thus, the occurrence of this type of interaction - namely studentstudent $(\mathrm{S}>\mathrm{S})$ - is relatively high and accounts for $22 \%(n=68)$.

According to the findings, the managerial strategies make up $21 \%$ of interactions ( $n=$ 66) and they are strictly related to the teacher-student $(\mathrm{T}>\mathrm{S})$ translanguaging practices. Their main function was to facilitate the process of learning and teaching, but also clarifying the instances where students could not cope with the imparted content. The most frequently used type of interaction involved giving instructions $(n=34)$. It constitutes $11 \%$ of all the translanguaging practices calculated in the present study. Other examples of managerial strategies relevant for the present study were as follows: providing feedback $(n=16)$, checking understanding $(n=7)$ and assigning homework $(n=9)$.

In the last type of strategies, the interpersonal ones, the main interactors were the students who translanguaged in their own groups mainly to translate, interpret and request. The total number of 61 instances of all the studied speech acts were calculated (19.5\%). The most frequently chosen interaction concerned translating $(n=38)$ and it involved situations where classmates translated new notions to their peers in order to help them understand better 
the selected concepts. In requesting, however, two types of patterns were observed as far as the main interactorsare concerned. The translanguaging practices were always initiated by the students, but they were either directed towards other students or the teachers $(S>T, S>S)$. Both participating parties were fully active.

In conclusion, it needs to be stated that out of 312 examples of collected and discussed translanguaging interactions, it was impossible to classify 11 instances: $3.5 \%$ of all the studied speech acts did not fall within any of the categories discussed. It was much easier to categorise the interactions according to the task-referring or non-task-referring division since the content of translanguaging patterns was clear enough. The non-classifiable actions on the part of the students and teachers were random and unrelated to one another; however they composed all possible constellations as to who the interactors were.

\section{Conclusion}

As can be noticed, the results of the study revealed a few salient points that need to be further addressed and will probably inspire future research concerning translanguaging as a pedagogical strategy successfully implemented in schools even in officially monolingual countries, such as Poland. The first issue that has emerged refers to adopting the principles oriented to the simultaneous use of more than one language in the same lesson. The study confirms that speakers' repertoires are porous, fluid, overlapping, and versatile; furthermore, they exist in an ecological system of interdependence. What has also been assumed and further substantiated in the study is the omnipresent and intentional breaking of boundaries between individual languages viewed as discrete systems and employing whole linguistic repertoires in class by both the students and the teachers, as shown in numerous tasks performed by the students. As a result translanguaging facilitates and propagates a dynamic continuum of social and linguistic resources with the purpose of enhancing knowledge transmission in classroom instruction. The observed students disclosed their linguistic complexity reflecting their multilingual ways of establishing meaning and accessing knowledge about the world. The overall picture is that translanguaging practices provide a learning space for students where they juggle languages in order to achieve their assumed interactional and social goals. The juggling of languages was clearly depicted in the interactions among the students of various nationalities. Since each student has a different repertoire to choose from, it was necessary to demonstrate the multitude of languages spoken by them. 
Last but not least, it has to be clearly voiced that translanguaging practices must be explicitly advocated, because learning how to manage several languages nowadays is an important step in both increasing linguistic repertoires and assuming new linguistic identities cut across the existing ethnolinguistic boundaries. Consequently, it might be assumed that the students experienced translanguaging as liberating while at the same time their efforts were supported by the teachers who noticed the educational role of the strategy, owing to which they could gain and share highly complex knowledge in the teaching context expressed in a language which is foreign to many of them. It was the use of multiple codes in various modes that afforded both the students and teachers a rich opportunity for dual input, which further facilitated the acquisition and processing of information in the Geography classes in multiple languages simultaneously. The students obviously enjoyed giving output and receiving input in multiple languages.

Ultimately, it seems that for the investigated sample of students the translanguaging principle is acknowledged as being the norm and a natural way of communication, which facilitates the process of content learning, although it might still take time to recognise translanguaging as a resource or strategy in its own rights inside, and probably outside the classroom. This paper also proves that translanguaging is capable of transforming the process of teaching for multilingual students. In disrupting traditional ways in which language in education has been conceptualised, the translanguaging theory has the potential to transform not only the education landscape, but also our social landscape that is increasingly becoming more inequitable.

\section{References}

Baker, C. (2006). Foundations of bilingual education and bilingualism (4 $\left.4^{\text {th }} \mathrm{edn}\right)$. Clevedon: Multilingual Matters.

Beacco, J. (2005). Languages and language repertoires: Plurilingualism as a way of life in Europe. Strasbourg: Council of Europe.

Canagarajah, S. (2011). Translanguaging in the classroom: Emerging issues for research and pedagogy. Applied Linguistics Review 2, 1-28. DOI: https://doi.org/10.1515/9783110239331.1

Creese, A., \& Blackledge, A. (2010). Translanguaging in the bilingual classroom: A pedagogy for learning and teaching? The Modern Language Journal 94 (1), 103-115. DOI: https://doi.org/10.1111/j.1540-4781.2009.00986.x 
Díaz-Rico, L. T., \& Weed, K. Z. (2010). The cross-cultural, language, and academicdevelopment handbook ( $4^{\text {th }}$ edn). Boston, MA: Allyn and Bacon.

García, O. (2009). Bilingual education in the $21^{\text {st }}$ century: A global perspective. Oxford: Wiley-Blackwell.

García, O. (2011). From language garden to sustainable languaging: Bilingual education in a global world. Perspectives 34 (1), 5-9.

García, O., \& Leiva, C. (2013). Theorizing and enacting translanguaging for social justice. In A. Creese \& A. Blackledge (Eds.), Heteroglossia as practice and pedagogy (pp. 199216). New York: Springer. DOI: https://doi.org/10.1007/978-94-007-7856-6_11

García, O., \& Li, W. (2014). Translanguaging: Language, bilingualism and education. New York, NY: Palgrave Macmillan.

Górowska-Fells, M. (2012). Kluczowe dane o nauczaniu języków obcych w szkołach w Europie 2012. Języki Obce w Szkole 4, 51-56.

Gumperz, J. J., \& Hymes, D. H. (Eds.). (1972). Directions in sociolinguistics: The ethnography of communication. New York: Holt, Rinehart and Winston.

Heath, S. B., \& Street, B. V. (2008). On ethnography: Approaches to language and literacy Research. New York: Teachers College Press.

Hornberger, N., \& Link, H. (2012). Translanguaging and transnational literacies in multilingual classrooms: A biliteracy lens. International Journal of Bilingual Education and Bilingualism 15 (3), 261-278. DOI: https://doi.org/10.1080/13670050.2012.658016

Lewis, G., Jones, B., \& Baker, C. (2012). Translanguaging: Origins and development from school to street and beyond. Educational Research and Evaluation 18 (7), 641-654. DOI: https://doi.org/10.1080/13803611.2012.718488

Li, W. (2011). Moment analysis and translanguaging space: Discursive construction of identities by multilingual Chinese youth in Britain. Journal of Pragmatics 43 (5), 1222-1235. DOI: https://doi.org/10.1016/j.pragma.2010.07.035

Mazak, C. \& Herbas-Donoso, C. (2014). Translanguaging practices and language ideologies in Puerto Rican university science education. Critical Inquiry in Language Studies 11 (1), 27-49. DOI: https://doi.org/10.1080/15427587.2014.871622

Phillipson, R. (2015). English as threat or opportunity in European higher education. In S. Dimova, A. K. Hultgren, \& C. Jensen (Eds.), English-medium instruction in higher 
education in Europe (pp. 19-42). Berlin: Mouton de Gruyter. DOI: https://doi.org/10.1515/9781614515272-003

Romanowski, P.(2016). Some reflections on the idiosyncrasy of bilingual education in secondary schools in Poland. In S. Grucza, M. Olpińska, \& P. Romanowski (Eds.), Bilingual Landscape of the Contemporary World (pp. 173-188). Frankfurt am Main: Peter Lang.

Swain, M., \& Deters, P. (2007). New mainstream SLA theory: Expanded and enriched. Modern Language Journal 91(5), 820-836. DOI: https://doi.org/10.1111/j.15404781.2007.00671.x

Williams, C. (1996). Secondary education: Teaching in the bilingual situation. In C. Williams, G. Lewis, \& C. Baker (Eds.), The language policy: Taking stock, interpreting and appraising Gwynneds's language policy in education (pp.193-211). Llangefni: CAI.

\begin{abstract}
Author's information
Piotr Romanowski is Piotr Romanowski, $\mathrm{PhD}$ is Adjunct Professor at the Faculty of Applied Linguistics of the University of Warsaw, Poland. He authored over thirty scholarly papers. He has published one monograph and (co-)edited five other volumes. His background is in language education (TESOL), hence his academic interests evolve round multilingual education (recently translanguaging) as well as sociolinguistics, intercultural communication in foreign language teaching. He is a member of Editorial Boards of several international scholarly journals. He has lectured in the USA, Canada, New Zealand, Japan, Hong Kong, the UK, Iceland, Spain, Portugal and Malta. He participated in over thirty international conferences. He is the founding member of MultiLingNet - a network grouping scholars investigating multilingualism and multilingual education. E-mail: p.romanowski@uw.edu.pl
\end{abstract}

To cite this article:

Romanowski, P. (2019). Translanguaging in the Polish educational context: Lessons learnt from IB schools. Bellaterra Journal of Teaching \& Learning Language \& Literature, 12(1), 5-24. DOI: https://doi.org/10.5565/rev/jt13.795 